\title{
Michel de L'Hospital, Carmina. Livre III
}

\section{Maurizio Busca}

\section{(2) OpenEdition}

\section{Journals}

\section{Edizione digitale}

URL: https://journals.openedition.org/studifrancesi/21096

DOI: 10.4000/studifrancesi.21096

ISSN: 2421-5856

\section{Editore}

Rosenberg \& Sellier

\section{Edizione cartacea}

Data di pubblicazione: 1 décembre 2019

Paginazione: 563

ISSN: 0039-2944

\section{Notizia bibliografica digitale}

Maurizio Busca, «Michel de L'Hospital, Carmina. Livre III», Studi Francesi [Online], 189 (LXIII | III) | 2019,

online dal 01 mars 2020, consultato il 11 novembre 2021. URL: http://journals.openedition.org/ studifrancesi/21096 ; DOI: https://doi.org/10.4000/studifrancesi.21096

Questo documento è stato generato automaticamente il 11 novembre 2021.

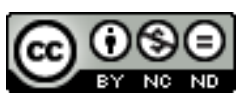

Studi Francesi è distribuita con Licenza Creative Commons Attribuzione - Non commerciale - Non opere derivate 4.0 Internazionale. 


\title{
Michel de L'Hospital, Carmina. Livre
}

\section{III}

\author{
Maurizio Busca
}

\section{NOTIZIA}

Michel de L'Hospital, Carmina. Livre III, sous la direction de P. Galand et L. Petris, édité, traduit et commenté par D. Amherdt, L. Chappuis Sandoz, P. Galand et L. Petris, avec la collaboration de Ch. Guerra et R. Stawarz-Luginbühl, Genève, Droz, 2018, «Travaux d'Humanisme et Renaissance» 592, 381 pp.

1 L'impresa di edizione, traduzione e commento dei Carmina di Michel de L'Hospital, avviata nel 2014 (rinviamo alla segnalazione del libro I apparsa nella Rassegna bibliografica del n. 175, p. 135, a cura di D. Cecchetti), si arricchisce di un terzo volume che raccoglie diciotto epistole metriche risalenti agli anni 1546-1570 ca., fra le quali si segnala una breve celebrazione dell'otium cum dignitate scritta in seguito alla caduta in disgrazia (1567). Conformemente al protocollo di edizione adottato nei volumi già pubblicati, di ogni epistola sono forniti testo, traduzione, presentazione del contesto di composizione, schema dell'articolazione del testo, analisi e commento filologico. Nei componimenti riuniti in questo terzo libro, molti dei quali di carattere encomiastico, appare particolarmente marcata l'opposizione fra campagna e città, ispirata all'evidente modello oraziano e nutrita dagli apporti di Boccaccio, Petrarca ed Erasmo. 